\title{
MODELLING RELIABILITY OF HENHOUSE MICROCLIMATE SYSTEMS WITH RISK ANALYSIS APPROACHES
}

\author{
Jerzy Napiórkowski* , Jarosław Gonera \\ Department of Construction, Exploitation of Vehicles and Machines, \\ University of Warmia and Mazury in Olsztyn \\ *Corresponding author: e-mail: napj@uwm.edu.pl
}

\begin{tabular}{|c|c|}
\hline ARTICLE INFO & ABSTRACT \\
\hline $\begin{array}{l}\text { Article history: } \\
\text { Received: March } 2017 \\
\text { Received in the revised form: } \\
\text { May } 2017 \\
\text { Accepted: June } 2017\end{array}$ & $\begin{array}{l}\text { The paper presents the issue of modelling reliability of microclimate. } \\
\text { It is very important to conduct the risk analysis in poultry farms in } \\
\text { order to indicate the most dangerous elements of the discussed system } \\
\text { in the aspect of maintaining usefulness. The main objective of the } \\
\text { paper was to carry out the risk analysis for the system that maintains }\end{array}$ \\
\hline $\begin{array}{l}\text { Key words: } \\
\text { risk analysis approaches, } \\
\text { farm, } \\
\text { poultry }\end{array}$ & $\begin{array}{l}\text { microclimate in a poultry farm. It was assumed in the paper that the } \\
\text { ventilation system influences maintaining microclimate in a henhouse. } \\
\text { Simultaneously, the most effective methods of risk reduction are } \\
\text { indicated and a rational assessment of the safety level is made. Studies } \\
\text { carried out in the paper enabled identification of the risk analysis } \\
\text { approach which the best reflects the issue of maintaining technical } \\
\text { equipment devices in operation. With the use of the matrix, the indica- } \\
\text { tor and probabilistic approach, the exploitation risk related to the } \\
\text { occurrence of previously defined failures of the henhouse ventilation } \\
\text { system was assessed. Based on the results of analysis, a conclusion } \\
\text { could have been made that concurrent results were obtained with the } \\
\text { use of the matrix and probabilistic approaches. In these cases, for all } \\
\text { failures the highest and the lowest exploitation risks of occurrence of } \\
\text { certain failures in the ventilation system in a henhouse were the same. }\end{array}$ \\
\hline
\end{tabular}

\section{Introduction}

A great number of undesired events occur in unpredictable moments and cause effects that cannot be predicted either. Often, these events are random and cause great human and material losses (Szopa, 2009). The risk defines probability of phenomena that negatively affect human life and health, environment and material goods. Risk is a possibility of various kinds of losses which result from undesired events. Losses on the part of threat are not obvious but raise along with the threat level. The risk analysis is a subjective assessment which may be defined directly or indirectly (Romanowska-Słomka and Słomka, 2008). The following risk measures can be distinguished: probability of an undesired event, absolute value of losses expressed with financial costs and the expected value of losses (Rak, 2003).

On poultry farms, maintaining suitable microclimate is shaped under the impact of weather, structure of buildings, specialist heating and ventilation devices, devices which provide feed and liquid for poultry and the number of poultry bred in henhouses. The poul- 
try production intensity, including the increase of automation of processes causes that a new approach for production security should be applied (Wessiani and Sarwoko, 2015). The most popular solutions concerning the risk analysis in poultry breeding concerned the aspect of poultry-human - pharmacological substances. For this type of cases, the analytical approach binding according to the guidelines of the National Research Council was developed (Poultry Inspection, 1987). The principles of maintaining suitable climatic conditions in Europe are provided in the regulation of the Minister of Agriculture and Rural Development (Journal of Laws of 2010, No 56, item 344 and Journal of Laws of 2010, No 116, item 778).

Three main elements: man, technical device and environment (work environment) influence the safety of machine use. The main role of the safety theory is prediction of losses which guarantee existence of the technique. The loss is an extreme form of negative consequence of lasting of a technical product in comparison to all elements of the man-technical device - environment system (Niziński, 2001).

The risk analysis is carried out in order to:

- indicate the most dangerous fragments of the considered system;

- indicate the most effective methods of risk reduction;

- rationally evaluate the safety level.

Increase of the risk analysis significance in order to improve the reliability of a technological line for poultry improvement is noticeable in many countries (Yang and Wang, 2015). Wessani and Sarwoko (2015) indicated the use of FMEA analysis in maintaining usefulness of devices in poultry farms.

Lack of detailed identification of events (Wang and Kieran, 2000) is a certain problem during the risk analysis in modern poultry farms, where many innovative technical solutions are applied. It results from considerably short exploitation of certain devices. In such cases, the risk analysis, which aims at identification of all possible undesired events, prediction of events, modelling possible scenarios and their analysis, plays a special role (Vaidya and Kumar, 2006). The risk analysis in such case is considerably influenced by randomness, incompleteness of input data and often lack of correlation between particular parameters related to functioning of technical devices in henhouses (Liu et al., 2005; Binaghi and Madella, 1999; Yang et al., 2008).

\section{Risk analysis methods}

There are many risk analysis methods. These are inter alia:

- quality approach: matrix and rate (Risk Score).

- quantity approach: probabilistic.

Quality approaches are used in order to identify the risk reduction approaches without the use of the quantity risk description (Rak, 2003).

The matrix quality approach may be used for comparison of the risk evaluations which are related to the undesired event. In this approach, classification of probability of occurrence of a certain event and identification of threats is carried out. Particular events are assigned to relevant cells in the plot. Based on this plot, the risk level is presented. In relation to the analysed system human-technique- surroundings, numbers of distinguished clas- 
Modelling reliability...

ses of threats and failure and criteria of division into classes may be varied (Rak and Tchórzewska-Cieślak, 2014; Szopa, 2009).

The second quality method is a rate method. It is used for assessment of the partial risk related to particular events. Among rate methods, Risk Score approach is the most popular (Kaczmarek, 2005). The most probable size of losses in the human-technical measures surrounding system is calculated with the use of the following formula:

$$
\mathrm{c}_{0}=\mathrm{u} \cdot \mathrm{q}_{1} \cdot \mathrm{Z}_{0}
$$

where:

$\mathrm{C}_{0} \quad-\quad$ the most probable size of losses in the system $\mathrm{H}-\mathrm{T}-\mathrm{S}$,

$\mathrm{u} \quad$ - frequency of exposition to threat,

$\mathrm{q}_{1} \quad-$ probability of event during one exposition,

$\mathrm{Z}_{0} \quad-$ size of losses.

Frequency of exposition to threat, probability of an event during one exposition and the size of losses are determined based on the traditional number scale (Kaczmarek, 2005).

The probabilistic approach is based on the reliability and threat models. They are most often used in the prognostic analysis. With the use of the probabilistic method, a more rational analysis may be conducted and a comparison can be made with relation to safety. Seven stages of the risk analysis with the use of the probabilistic approach can be distinguished (Figure 1).

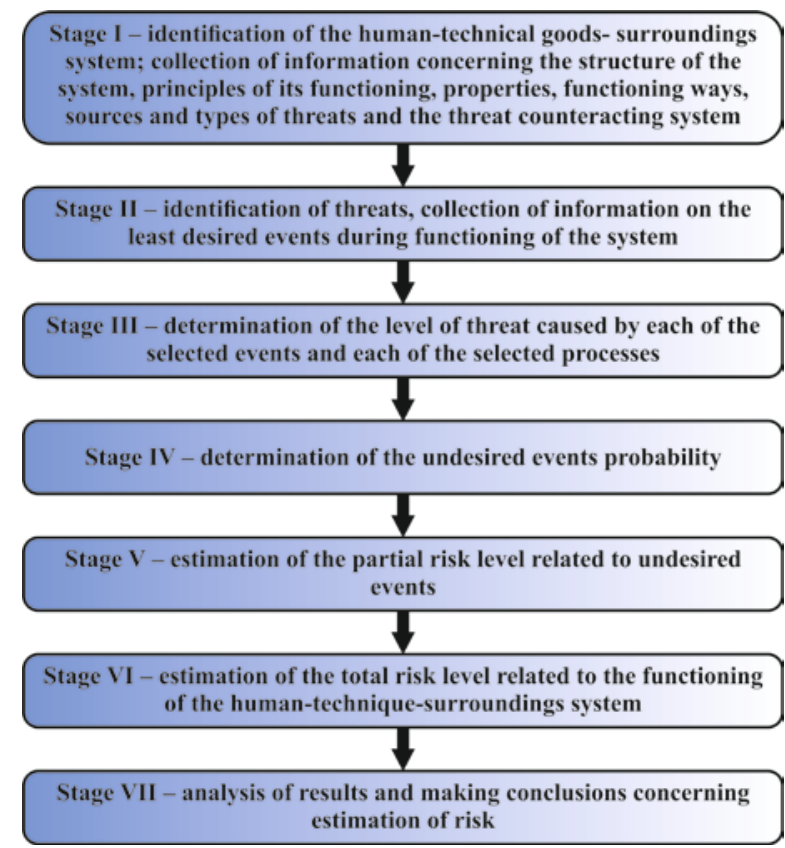

Figure 1. Algorithm of the risk analysis with the use of probabilistic method 


\section{Description of research}

The European Union states defined detailed requirements related to maintaining microclimate in poultry farms. These requirements included assurance of optimal scope of temperature and moisture in the henhouse. Suitable ventilation and amount of gas is also an important factor. The following values of hazardous gases concentration cannot be exceeded in a henhouse (www.arka.strefa.pl):

- carbon dioxide - $2500 \mathrm{ppm}$,

- ammonia - 20 ppm,

- hydrogen sulphide - 5 ppm.

Heater, humidification system and ventilation system influence the proper microclimate in a henhouse. Requirements concerning the internal environment depend on the type of bred birds. For example, in the period of a 6-week cycle of breeding of a broiler, the temperature changes with animal age (Figure 2) changes of temperature in a henhouse during broiler breeding were presented. Figure 3 presents a daily temperature course and moisture in a heated henhouse on the 7th, 35th and 54th day of breeding of a broiler in winter seasons. The ventilation system has the biggest impact on the microclimate in a henhouse. Therefore, the risk analysis was carried out based on the data concerning the ventilation system. In a henhouse, where modelling of reliability of microclimate systems was carried out, there was a roof-tunnel system, presented in figure 4.

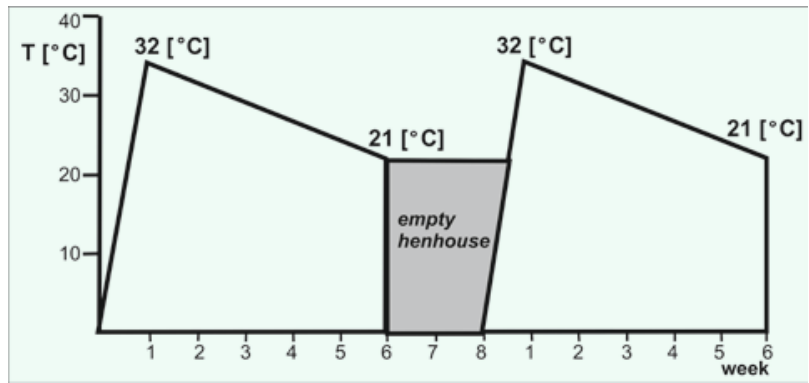

Figure 2. Broiler breeding cycle (www.instalacjebudowlane.pl)

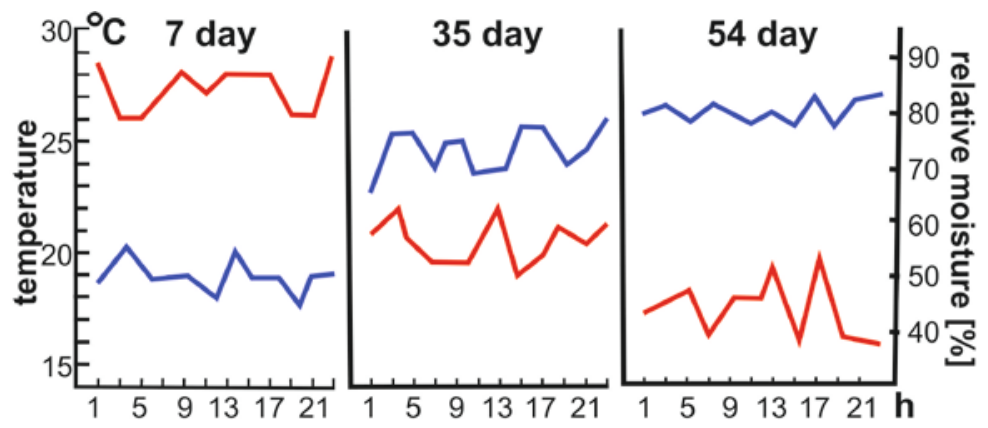

Figure 3. Daily course of temperature and moisture in a heated henhouse on the 7th, 35th and 54th day of feeding a broiler in winter months (Gizex Technika Ciepłownicza, 2012) 
Modelling reliability...

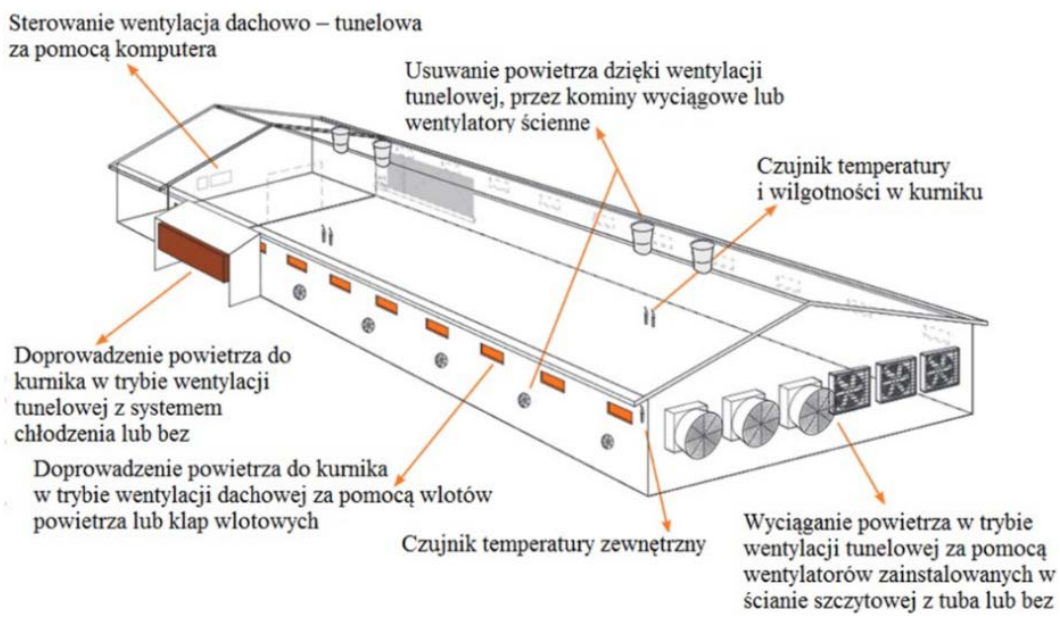

Figure 4. Roof and tunnel ventilation system (www.bigdutchman.pl)

The main objective of the paper is to carry out the risk analysis for the system that maintains microclimate on the poultry farm. Analysis will be carried out with the use of three independent risk analysis approaches. Thus, results from particular risk analysis approaches will be compared. It was assumed in the paper that the ventilation system is the main element of the system responsible for maintaining microclimate which has the biggest impact on the microclimate.

The scope of research:

- identification of damages and threats which occur on poultry farms,

- modelling of reliability of three risk analysis methods,

- analysis of the obtained results from three risk analysis methods.

Data indispensable for the risk analysis for the ventilation system in a henhouse were collected based on the information obtained from the employees of the company which deals with poultry farm equipment in Poland. The company employees are persons with a several-year experience on the position of electronic engineer, electrician, mechanic, gas worker and repairman. The obtained information concerned:

- frequency of damages in a given device,

- reasons for damages,

- threats which cause damage for the ventilation system and for the bred herd.

Reliability was modelled with the use of the following risk analysis approaches: matrix quality, indicators quality and quantity probabilistic approach. The selected approaches present a different approach than the risk analysis issue; thus, it will be possible to compare the obtained results from particular methods and selecting the most advantageous one.

It was stated that the following damage with relevant denotations may occur in the ventilation system:

- A(1) - failure of the elevator control engine,

- A(2) - failure of the inlet system,

- A(3) - failure of the inlet rod,

- A(4) - failure of the flap opening mechanism, 
- A(5) - failure of the flap opening mechanism engine,

- $A(6)$ - failure of the fan engine,

- A(7) - failure of the fan,

- $A(8)$ - failure of the moisture sensor.

\section{Results of risk analysis research}

\section{Matrix approach}

In the risk analysis for the ventilation system in a henhouse, firstly, the significance of consequences and probability of a given event with the use of three-point scale for each analysed threats was estimated. Particular events were placed in relevant matrix cells. Based on this matrix, the risk of particular damages may be read out since respective number defining the risk level may be read out. The risk matrix was made for particular elements of the ventilation system (Fig. 5) and comparison of the given threats risk was presented in figure 6 .

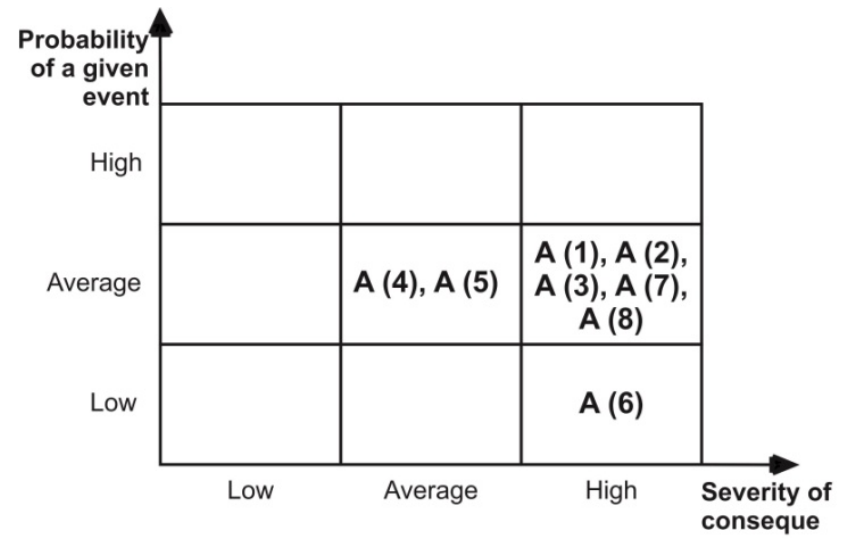

Figure 5. Risk matrix for particular elements of ventilation system

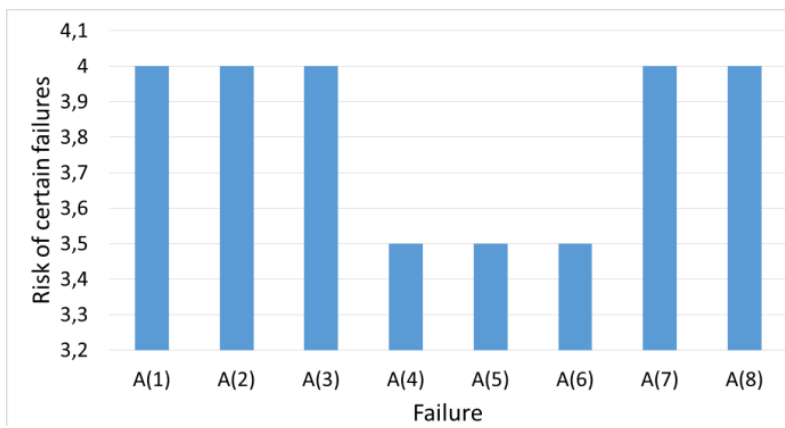

Figure 6. Comparison of risk of particular threats (A1-8) according to matrix approach 
Modelling reliability...

Based on the obtained data it was stated that the highest risk of an event concerned five failures of the ventilation system of a henhouse: elevator engine, inlet system, inlet rod, fan and moisture sensor. Considerably lower risk of occurrence concerned the remaining damages $-\mathrm{A}(4), \mathrm{A}(5)$ and $\mathrm{A}(6)$.

\section{Indicator approach}

The risk analysis with the indicator approach enabled to carry out analysis of data from traditional number scales firstly. These data were presented in table 1, 2 and 3 and the number values were assigned to them according to the literature data (Szopa, 2009).

Table 1.

Frequency of exposition to threat

\begin{tabular}{lc}
\hline Exposition - E & $\begin{array}{c}\mathrm{u} \\
\text { (point scale) }\end{array}$ \\
\hline Constant & 10 \\
Very frequent & 6 \\
Frequent & 3 \\
From time to time & 2 \\
Rare & 1 \\
Minimal & 0,5 \\
\hline
\end{tabular}

Table 2.

Probability of occurrence of undesired event during one exposition

Characteristic - P

Probability $\mathrm{q}_{1}$ (point scale)

Very probable

Quite possible

Practically possible

Less probable

Possible only from time to time

Possible to think about

Theoretically possible

Table 3.

Size of exploitation losses

\begin{tabular}{lc}
\hline Characteristics - S & $\begin{array}{c}\mathrm{Z}_{0} \\
\text { (point scale) }\end{array}$ \\
\hline Fixed elimination of a device & 100 \\
Long-term stoppage at work & 40 \\
Temporary stoppage at work & 15 \\
Short-term stoppage at work & 7 \\
Impeded work & 3 \\
Possibility of continuing of work despite the failure & 1 \\
\hline
\end{tabular}

10
6
3
1
0.5
0.2
0.1

6

3

1

0.5

0.2

0.1 
Based on the data set in tables, the risk related to particular elements of the ventilation system in a henhouse was compared. Results of this analysis were set in table 4 and additionally in the plot (Fig. 7). Partial risk related to the specific event was marked as $\mathrm{c}_{0}$ and calculated from the relation:

$$
\mathrm{c}_{0}=\mathrm{u} \cdot \mathrm{q}_{1} \cdot \mathrm{Z}_{0}
$$

Table 4.

Results of Risk Score analysis

\begin{tabular}{lcccc}
\hline Damage & Damage & $\mathrm{q}_{1}(\mathrm{P})$ & $\mathrm{Z}_{0}(\mathrm{~S})$ & $\begin{array}{c}\mathrm{c}_{0}=\mathrm{u} \cdot \mathrm{q}_{1} \cdot \mathrm{Z}_{0} \\
(\mathrm{R}=\mathrm{P} \times \mathrm{E} \times \mathrm{S})\end{array}$ \\
\hline $\mathrm{A}(1)$ & 2 & 3 & 100 & 600 \\
$\mathrm{~A}(2)$ & 2 & 3 & 3 & 18 \\
$\mathrm{~A}(3)$ & 0.5 & 0.5 & 100 & 25 \\
$\mathrm{~A}(4)$ & 1 & 6 & 100 & 600 \\
$\mathrm{~A}(5)$ & 0.5 & 3 & 100 & 150 \\
$\mathrm{~A}(6)$ & 1 & 3 & 100 & 300 \\
$\mathrm{~A}(7)$ & 1 & 3 & 100 & 300 \\
$\mathrm{~A}(8)$ & 1 & 3 & 1 & 3 \\
\hline
\end{tabular}

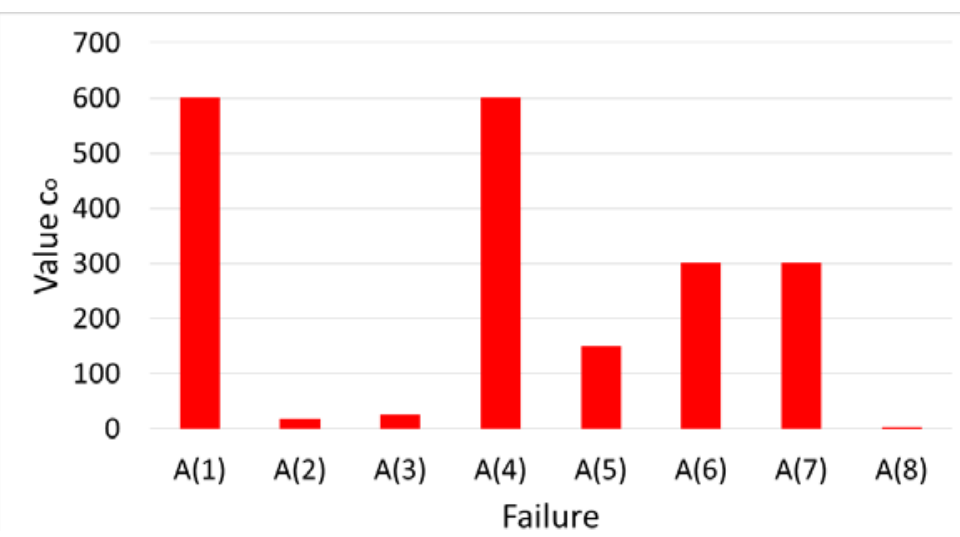

Figure 7. The plot presenting comparison of the risk of particular elements of the ventilation system of a henhouse with the indicator approach

Based on the obtained results for the ventilation system with the use of the indicator approach, it was stated that the highest partial risk of the occurrence of the event referred to the damage of the elevator engine and damage to the flap opening mechanism. On the other hand, very low partial risk of the occurrence of the event was related to damages to the moisture sensor, inlet system and inlet rod $-A(2), A(3)$ and $A(8)$. 


\section{Probabilistic approach}

Firstly, the human-technique- surroundings system was recognized. The probabilistic method comprised a few presented stages.

\section{Stage I: Recognition of the H-T-S system}

The ventilation system in a henhouse was controlled with the use of a computer. This system comprised air inlets, roof air outlets and peak air outlets. The ventilation system worked:

- in relation to the weather conditions and the season of the year with varied intensity;

- $\quad$ for the entire year;

- entire day.

\section{Stage II: Identification of threats}

Identification of threats related to the ventilation system functioning in a henhouse was carried out. These threats were related to main elements of the system:

- air inlets: damage to the elevator engine, inlet system, inlet rod;

- roof air outlet: damage to the flap opening mechanism, engine of the flap opening mechanisms, fan engine;

- top air outlets damage to fan, moisture sensor.

Stage III: Determination of the threat level $Z^{(k)}$ (c) of each of events $A^{(k)}$ and probability of $Q^{(k)}$ of their occurrence - quality evaluation was set in table no. 5 .

Table 5.

Quality assessment of the threat level

\begin{tabular}{|c|c|c|c|c|c|}
\hline$A^{(k)}$ & Failure & $\begin{array}{l}Z^{(\mathrm{k})}(\mathrm{c}) \text {, } \\
\text { where: }\end{array}$ & $Q^{(k)}(t=1 h)$ & $\mathrm{Q}^{(\mathrm{k})}(\mathrm{t}=4 \mathrm{~h})$ & $\mathrm{Q}^{(\mathrm{k})}(\mathrm{t}=8 \mathrm{~h})$ \\
\hline $\mathrm{A}^{(1)}$ & failure of the elevator engine & 12 & 3 & 12 & 24 \\
\hline$A^{(2)}$ & failure of the inlet system & 12 & 3 & 12 & 24 \\
\hline$A^{(3)}$ & failure of the inlet rod & 12 & 4 & 16 & 32 \\
\hline$A^{(4)}$ & $\begin{array}{l}\text { failure of the flap opening } \\
\text { mechanism }\end{array}$ & 12 & 4 & 16 & 32 \\
\hline$A^{(5)}$ & $\begin{array}{l}\text { failure of the flap opening } \\
\text { mechanism engine }\end{array}$ & 12 & 4 & 16 & 32 \\
\hline$A^{(6)}$ & failure of the fan engine & 8 & 2 & 8 & 16 \\
\hline$A^{(7)}$ & failure of the fan & 8 & 2 & 8 & 16 \\
\hline$A^{(8)}$ & failure of the moisture sensor. & 8 & 2 & 8 & 16 \\
\hline
\end{tabular}


Jerzy Napiórkowski, Jarosław Gonera

\section{Stage V: Determination of the partial risk level}

Determination of the partial risk level of the ventilation system in three various times was presented in table 6 and 7. During determination of the risk level, the following relation was used:

$$
\Delta^{(\mathrm{K})}(\mathrm{c}, \mathrm{t})=\mathrm{Q}^{(\mathrm{k})}(\mathrm{t}) \cdot \mathrm{Z}^{(\mathrm{k})}(\mathrm{c})
$$

where:

$Q^{(k)}(t) \quad-$ probability of the occurrence of the event

$Z^{(k)}$ (c) - the level of threat for particular events

Table 6.

The partial risk level of the failure of the ventilation system which causes losses C4

\begin{tabular}{|c|c|c|c|c|}
\hline \multirow{15}{*}{ c4 } & \multirow{3}{*}{$\Delta 1$} & $t=1$ & 36 & \multirow{3}{*}{ failure of the elevator engine } \\
\hline & & $t=4$ & 144 & \\
\hline & & $t=8$ & 288 & \\
\hline & \multirow{3}{*}{$\Delta 2$} & $t=1$ & 36 & \multirow{3}{*}{ failure of the inlet system } \\
\hline & & $t=4$ & 144 & \\
\hline & & $t=8$ & 288 & \\
\hline & \multirow{3}{*}{$\Delta 3$} & $t=1$ & 16 & \multirow{3}{*}{ failure of the fan engine } \\
\hline & & $t=4$ & 64 & \\
\hline & & $t=8$ & 128 & \\
\hline & \multirow{3}{*}{$\Delta 4$} & $t=1$ & 16 & \multirow{4}{*}{ failure of the fan } \\
\hline & & $t=4$ & 64 & \\
\hline & & $\mathrm{t}=8$ & 128 & \\
\hline & \multirow{3}{*}{$\Delta 5$} & $\mathrm{t}=1$ & 16 & \\
\hline & & $\mathrm{t}=4$ & 64 & \multirow[t]{2}{*}{ failure of the moisture sensor. } \\
\hline & & $\mathrm{t}=8$ & 128 & \\
\hline
\end{tabular}

Table 7.

The partial risk level of the failure of the ventilation system which causes losses C2

\begin{tabular}{ccccc}
\hline \multirow{4}{*}{$\Delta 1$} & $\mathrm{t}=1$ & 48 & \\
& $\mathrm{~T} 4$ & 192 & failure of the inlet rod \\
& $\mathrm{t}=8$ & 384 & \\
& $\mathrm{t}=1$ & 48 & failure of the flap opening mecha- \\
& \multirow{4}{*}{$\Delta 2$} & $\mathrm{t}=4$ & 192 & nism \\
& & $\mathrm{t}=8$ & 384 & \\
& $\mathrm{t}=1$ & 48 & failure of the flap opening mecha- \\
& \multirow{2}{*}{$\Delta 3$} & $\mathrm{~T} 4$ & 192 & nism engine \\
& $\mathrm{t}=8$ & 384 & \\
\hline
\end{tabular}


Modelling reliability...

\section{Stage VI: Determination of the total risk level}

The total risk level related to the ventilation system in a henhouse in relation to the hours of operation was determined.

The total risk after one hour of operation:

$$
\begin{gathered}
\Delta(\mathrm{c}, \mathrm{t}=1 \mathrm{~h})=\Sigma^{(1-8)} \Delta^{(\mathrm{k})}(\mathrm{c}, \mathrm{t}=1 \mathrm{~h}) \\
\Delta(\mathrm{c}, \mathrm{t}=1 \mathrm{~h})=264
\end{gathered}
$$

The total risk after one hour of operation:

$$
\begin{gathered}
\Delta(\mathrm{c}, \mathrm{t}=4 \mathrm{~h})=\Sigma^{(1-8)} \Delta^{(\mathrm{k})}(\mathrm{c}, \mathrm{t}=4 \mathrm{~h}) \\
\Delta(\mathrm{c}, \mathrm{t}=4 \mathrm{~h})=1056
\end{gathered}
$$

The total risk after eight hours of operation:

$$
\begin{gathered}
\Delta(\mathrm{c}, \mathrm{t}=8 \mathrm{~h})=\Sigma^{(1-8)} \Delta^{(\mathrm{k})}(\mathrm{c}, \mathrm{t}=8 \mathrm{~h}) \\
\Delta(\mathrm{c}, \mathrm{t}=8 \mathrm{~h})=2112
\end{gathered}
$$

\section{Analysis of the obtained results}

Based on the results obtained from all three risk analysis approaches, the highest and the

\begin{tabular}{|c|c|c|c|}
\hline \multicolumn{4}{|c|}{ Exploitation risk } \\
\hline Damage & Matrix approach & Indicator approach & $\begin{array}{c}\text { Probabilistic } \\
\text { approach }\end{array}$ \\
\hline Failure of the elevator engine & the highest & the highest & the highest \\
\hline Of the inlet system & the highest & average & the highest \\
\hline Of the inlet rod & the lowest & average & the lowest \\
\hline Of the flap opening mechanism & the lowest & the highest & the lowest \\
\hline Of the flap opening mechanism & the lowest & average & the lowest \\
\hline Of the fan engine & the highest & average & the highest \\
\hline Of the fan & the highest & average & the highest \\
\hline Of the moisture sensor. & the highest & the lowest & the highest \\
\hline
\end{tabular}
lowest exploitation risk of particular damage were determined for the ventilation system (Table 8).

Table 8.

Comparison of the results obtained with the use of the matrix, indicator and probabilistic approach

Based on the results of analysis, one could have concluded that concurrent results were obtained with the use of the matrix and probabilistic approach. For all failures, the highest 
and the lowest exploitation risks of occurrence of particular failures in the ventilation system in a henhouse were the same.

Moreover, with the use of the probabilistic approach, additionally, the highest and the lowest risk of occurrence of failures was determined and it was as follows:

The highest risk of occurrence of failure was identified for;

- failure of the inlet rod, flap opening mechanisms and flap opening mechanisms engine.

The lowest risk of occurrence of failure was identified for:

- damage to the fan engine, fan and moisture sensor damage.

\section{Conclusions}

The probabilistic method enables the most detailed risk analysis. In the paper, the ventilation system which is located in the poultry farm buildings was selected as a system the most responsible for maintaining the suitable microclimate in the poultry farm. Failures of the henhouse ventilation system may cause disruption of the entire hen breeding cycle.

The probabilistic approach may identify the highest number of elements which cause the highest and the lowest exploitation risk.

In case of each risk analysis method for the entire ventilation system on the poultry farm, it was stated that the failure of the elevator control system causes the highest exploitation risk.

In case of the probabilistic and matrix approach the same damages responsible for the highest exploitation risk and the same failures responsible for the lowest exploitation risk were identified.

Based on the analysis of results obtained with the use of the indicator approach, one may notice that the risk level related to the damage of the elevator control engine and failure of the flap opening mechanisms is considerably higher than for the remaining failures. The difference may be of several dozens or even several hundreds. Considerable differences at the level of threats for particular failures may be reported after the application of the risk analysis with the use of the probabilistic approach. Based on which the risk of a failure to the fan engine, fan and moisture sensor is lower than the remaining ones. Each of the analysed approaches may be used for analysis of reliability of functional systems on poultry farms. Precise forecasts of failure of functioning raise with the complexity of the applied approach.

\section{References}

Binaghi, E., Madella, P. (1999). Fuzzy Dempster-Shafer reasoning for rule-based classifiers. International Journal of Intelligent Systems 4(2), 124-131.

Gizex, Technika Ciepłownicza (2012). Wybór sposobu ogrzewania i jego wpływ na hodowlę drobiu. Hodowca drobiu, 12, 56-65.

Kaczmarek, T. T. (2005). Ryzyko i zarządzanie ryzykiem: ujęcie interdyscyplinarne. Difin, Warszawa, ISBN: 978-83-7641-280-1. 
Modelling reliability...

Liu, J., Yang, J.B., Wang, J., Sii, H.S. (2005). Engineering system safety analysis and synthesis using the fuzzy rule-based evidential reasoning approach. Quality and Reliability Engineering International, 21(4), 387-411.

Niziński, S. (2002). Eksploatacja obiektów technicznych. Wydawnictwo i Zakład Poligrafii Instytutu Technologii i Eksploatacji, Warszawa, ISBN 83-7204-284-5.

Poultry Inspection (1987). The Basic for a Risk-Assessment Approach. National Research Council (US) Commitlee an Public Health Risk Assessment of Poultry Inspection Programs, Washington.

Rak, J. (2003). Metoda szacowania ryzyka zagrożenia systemu zaopatrzenia w wodę. Ochrona Środowiska. Polskie Zrzeszenie Inżynierów i Techników Sanitarnych, 25, 33-36.

Rak, J., Tchórzewska-Cieślak, B. (2014). Matrycowe metody analizy ryzyka awarii infrastruktury komunalnej. Czasopismo inżynierii lądowej, środowiska i architektury; Budownictwo i Inżynieria Środowiska, 233-244.

Romanowska-Słomka, I., Słomka, A. (2008). Zarzadzanie ryzykiem zawodowym. Wydanie VI, Kraków-Tarnobrzeg, ISBN 978-83-7394-239-4.

Szopa, T. (2009). Niezawodność i bezpieczeństwo. Oficyna Wydawnicza Politechniki Warszawskiej, Warszawa, ISBN: 978-83-7814-555-4.

Vaidya, O.S., Kumar, S. (2006). Analytic hierarchy process: an overview of applications. European Journal of Operational Research, 169(1), 1-29.

Wang, J., Kieran, O. (2000). Offshore safety assessment and safety based decision making - the current status and future aspects. Journal of Offshore Mechanics and Arctic Engineering, 122(2), 63-69.

Wessiani, N. A., Sarwoko, S. O. (2015). Risk analysis of poultry feed production using fuzzy FMEA Industrial Engineering and Service Science, 517-528.

Yang, Z.L., Bonsall, S., Wang, J. (2008). Fuzzy rule-based Bayesian reasoning approach for prioritization of failures in FMEA. IEEE Transactions on Reliability, 57, 517-528.

Yang, Z., Wang, J. (2015). Use of fuzzy risk Assessment in FMEA of offshore engineering systems. Ocean Engineering, 95, 195-204.

Rozporządzenie Ministra Rolnictwa i Rozwoju Wsi z dnia 15 lutego 2010r. w sprawie wymagań i sposobu postepowania przy utrzymaniu gatunków zwierząt gospodarskich, dla których normy ochrony zostały określone w przepisach Unii Europejskiej (DZ.U. 2010 nr 56 poz. 344 z późn $\mathrm{zm}$.).

Rozporzadzenie Ministra Rolnictwa i Rozwoju Wsi z dnia 28 czerwca 2010r. w sprawie minimalnych warunków utrzymania gatunków zwierząt gospodarskich innych niż te, dla których normy ochrony zostały określone w przepisach Unii Europejskiej (DZ.U. $2010 \mathrm{nr} 116$ poz. 778 z późn zm.).

www.arka.strefa.pl

www.bigdutchman.pl

www.instalacjebudowlane.pl 


\section{MODELOWANIE NIEZAWODNOŚCI SYSTEMÓW MIKROKLIMATU KURNIKÓW METODAMI ANALIZY RYZYKA}

Streszczenie. W pracy przedstawiono zagadnienie modelowania niezawodności mikroklimatu. Na fermach drobiu niezmiernie ważne jest przeprowadzenie analizy ryzyka w celu wskazania najbardziej niebezpiecznych elementów rozpatrywanego systemu w aspekcie utrzymania stanu zdatności. Głównym celem pracy było dokonanie analizy ryzyka dla systemu odpowiedzialnego za utrzymanie mikroklimatu na fermie drobiu. W pracy przyjęto, że elementem mającym największy wpływ na utrzymanie mikroklimatu w kurniku jest system wentylacji. Równocześnie wskazywane są najskuteczniejsze sposoby zmniejszenia ryzyka i dokonywana jest racjonalna ocena poziomu bezpieczeństwa. Przeprowadzone $\mathrm{w}$ pracy badania umożliwiły zidentyfikowanie, która ze stosowanych metod analizy ryzyka najlepiej odzwierciedla zagadnienie utrzymania w ruchu urządzeń wyposażenia technicznego kurnika. Z wykorzystaniem metody matrycowej, metody wskaźnikowej oraz metody probabilistycznej oszacowano ryzyko eksploatacyjne związane $\mathrm{z}$ wystąpieniem wcześniej zdefiniowanych uszkodzeń systemu wentylacji kurnika. Na podstawie wyników analiz można było wywnioskować, że korzystając z metody matrycowej oraz probabilistycznej otrzymano zbieżne wyniki. $\mathrm{W}$ tych przypadkach dla wszystkich uszkodzeń pokrywały się największe oraz najmniejsze ryzyka eksploatacyjne wystapienia poszczególnych uszkodzeń w systemie wentylacji w kurniku.

Słowa kluczowe: metody analizy ryzyka, ferma, drób 